\title{
Thyroid Cancer pMX TNM Finding v6
}

National Cancer Institute

\section{Source}

National Cancer Institute. Thyroid Cancer pMX TNM Finding v6. NCI Thesaurus. Code C60799.

Thyroid cancer in which the status of distant metastasis cannot be assessed. (from AJCC 6th Ed.) 